\title{
Yabancılara Türkçe Öğretiminde Yazma Becerisine Yönelik Web 2.0 Araçları: Poll Everywhere Örneği*
}

\author{
Web 2.0 Tools for Writing Skills in Teaching Turkish \\ as a Foreign Language: Poll Everywhere Sample
}

\author{
Bayram BAŞ**, Osman TURHAN***
}

\begin{abstract}
Öz: Yabancılara Türkçe öğretimi sürecinde de kullanılabilecek olan Web 2.0 araçları, sundukları dijital ortamlarla öğrencilerin üretici dil becerilerine katkı sağlamaktadır. Bu çalışmada, Web 2.0 araçlarından Poll Everywhere'in Türkçeyi yabancı dil olarak öğrenen öğrencilerin yazma becerilerine yönelik etkisi, öğrenci görüşleri doğrultusunda değerlendirilmiştir. Nitel araştırma yöntemlerinden iç içe geçmiş tek durum deseninin kullandığı araştırmada Poll Everywhere ile geliştirilmiş üç adet etkinlik kullanılarak B1 seviyesinde Türkçe öğrenen öğrencilerle uygulama yapılmıştır. Uygulama sonrasında öğrencilerden Poll Everywhere Web 2.0 aracına ve geliştirilen etkinliklere yönelik elde edilen veriler içerik analizi ile değerlendirilmiştir. Çalışmada Poll Everywhere Web 2.0 aracının olumlu sıfatlarla tanımlandığı, interaktif bir eğitim ortamının çeşitli özelliklerini sunduğu, yazmaya yönelik isteği arttırdığı ve yazma derslerinde devamlı kullanılmak istendiği sonucuna ulaşılmıştır. Yazma etkinliklerine yönelik sonuçlar ise "etkinliklerin olumlu sıfatlarla tanımlanması, geleneksel ders kitabına göre daha çeşitli firsatlar sunması, iletişimsel bir yapıda olması, zihinsel becerileri desteklemesi, Poll Everywhere Web 2.0 aracı ile uyumlu olması" şeklinde çeşitlenmiş̧ir.
\end{abstract}

Anahtar Kelimeler: Web 2.0 araçları, Poll Everywhere, yazma becerisi, yabancılara Türkçe öğretimi

\begin{abstract}
Web 2.0 tools which can also be used in teaching Turkish as a foreign language classrooms help to improve productive language skills by digital teaching environments that they offer. In this study, the impact of Poll Everywhere, which is a Web 2.0 tool, on writing skills of students who are learning Turkish as a foreign language is evaluated in terms of student opinions. Embedded single case study which is a qualitative method is used in this study and three activities developed with Poll Everywhere are applied to students learning Turkish as a foreign language at B1 level. The data obtained from students upon the application of Poll Everywhere and the activities are evaluated by content analysis. Findings of this study suggest that Poll Everywhere is providing an interactive educational environment with various features, is increasing the desire for writing, and students want Poll Everywhere to be used in writing lessons constantly. Findings regarding the writing activities prove that they have positive connotations, offer more opportunities in comparison with course books, have communicative features, promote cognitive skills, and correspond to Poll Everywhere Web 2.0 tool.
\end{abstract}

Keywords: Web 2.0 tools, Poll Everywhere, writing skills, teaching Turkish as a foreign language

\section{Giriş}

Yazma becerisi, yabancılara Türkçe öğretimi sürecinde "dil bilgisi kurallarının kullanımı, şekil bilgisi ve cümle bilgisi farkındalığı, söz varlığı düzeyi” vb. ölçütleri dayanak alarak gelişim gösterir. Sınıf ortamında ve sınıf dışında oluşturulacak yazmaya yönelik eğitim durumlarının yukarıda sıralanan ölçütleri taşıması gerekir. Bu doğrultuda geleneksel yazma çalışmaları yanında özellikle teknolojinin günümüzde geldiği seviye çerçevesinde geliştirilen Web 2.0 araçlarının kullanımı da önem kazanmaktadır. İletişim boyutuyla alternatif yazma süreçlerine

\footnotetext{
*Bu çalışma Uluslararası Yabancı Dil Öğretimi ve Yabancı Dil Olarak Türkçe Öğretimi Sempozyumu’nda (27-28 Nisan 2017, Bursa) "Yabancilara Türkçe Öğretiminde Yazma Becerisine Yönelik Etkinlikler: Poll Everywhere Örneği”" adıyla sunulan sözlü bildirinin genişletilmiş hâlidir.

**Doç. Dr., Yıldız Teknik Üniversitesi, Eğitim Fakültesi, İstanbul-Türkiye, e-posta: bbas@yildiz.edu.tr

***Arş. Gör., Yıldız Teknik Üniversitesi, Eğitim Fakültesi, İstanbul-Türkiye, e-posta: osmant@ yildiz.edu.tr
} 
olanak tanıyan Web 2.0 araçları ile oluşturulacak yazma çalışmaları, yazma sürecinin yapı taşlarına yeni boyutlar kazandırabilecektir.

Web 2.0 araçları ile düzenlenen eğitim ortamlarının bir boyutunu oluşturan iletişimsel boyut, yazma becerisi ile yakından ilişkilidir. Aktaş (2005, s. 91) iletişim aracılığıyla fikirlerin, duyguların ve bilgilerin karşılıklı bir şekilde aktarılabildiğini ifade etmektedir. Bu sayede kişiler, yaşadığı çevreyi daha iyi algılayabilmekte, değerlendirme ve yorumlamalar yapabilmektedir. $\mathrm{Bu}$ yaklaşımda metinler, iletişim gayesiyle oluşturulur. İletişimin gerçekleşebilmesi içinse metnin bir okur tarafından okunması gerekir. Ancak yazar okurla bağ kurduğunda ve yazarın ürettiği metin okurda etki bıraktığında iletişimsel yazma gerçekleşebilir (Ülper, 2008). İletişimsel yaklaşımda oluşturulan yazma etkinliklerinde öğrencilerin istek ve ihtiyaçlarını göz önünde bulundurulur. Etkinlikler, yazma süreci boyunca öğrenci merkezlidir ve öğrencilerin motivasyonunu arttırmalıdır. Bu yaklaşımda kullanılacak materyaller özgün olmalıdır. Materyaller, öğrenciyi tekdüzelikten kurtarıp eğlenceli vakit geçirmesini sağlamalıdır. Seçilen materyaller içerik ve düzey açısından öğrenci seviyesine uygun olmalıdır. Kullanılacak materyaller günlük hayattan kopuk olmamalı, ilişkisiz bağlantılardan oluşmamalıdır (Adıyaman, 2011, s. 17-18). Materyalleri kullanan öğrenciden beklenen, dil kurallarının ezberlemesi değil bu kurallara yazma uygulamasında yer vermesidir (Hamaratl1, 2015). Ayrıca iletişimsel yaklaşımda; sorun çözme, grup çalışması, ikili çalışma gibi teknikler ve yaratıcılığı geliştirmeye yönelik sınıf içi etkinlikler de kullanabilmektedir (Özcan, 2014, s. 156).

Yazılı anlatımda "yeteri kadar yazma konusunun bulunması, bulunan konuların anlamlı olması, öğrenci eserlerinin bir okuyucunun olması, öğrencilerin beraber çalışması" (Raimes, 1983) gibi hususlara dikkat edilmesi yazma sürecinden verim alınabilmesi için önemlidir. Örneğin; farklı ülkelerden ve kültürlerden, farklı dil ailelerinden hedef dili öğrenmek için gelmiş öğrencileri ortak kavramlar ve durumlar etrafında toplamak gerekmektedir. Bu öğrencilerin her biri için ortak konuların bulunması, bulunan konuların her bir öğrenci için anlam ifade etmesi ve grup çalışmasına uygun olması gerekmektedir. Bu da öğrenilen dilin coğrafyası özümsenene kadar ancak ortak/evrensel kavramları ve durumları yazma odağı haline getirmekle mümkün olacaktır. Ayrıca Barın (2006, s. 30) küçük yarışmalarla rekabet ortamında yazı yazmanın teşvik edilmesine, hikâye tamamlama gibi etkinliklerden faydalanılmasına, yazma uğraşının eğlenceli ve zevkli hâle getirilmesine dikkat edilmesi gerektiğini belirtmiştir. Widowson'a (1984, s. 64) göre yazmanın sıkıcı bir etkinlik hâline gelmemesi için dil kurallarını öğretmeye odaklanılmamalı, dilin akıcılığına, iletişimin amaçlarına ve öğrencilerin içsel güdülerine dikkat edilmelidir (Aktaran Kuş ve Bakır, 2013, s. 396). Yazma becerisinin tematik yönüne dair bu hususlar, Web 2.0 araçları ile hazırlanacak eğitim ortamları için de geçerlidir.

Yazma becerisinin gelişimine yönelik kullanılabilecek birçok Web 2.0 aracı bulunmaktadır. Bu Web 2.0 araçları, öğrencinin yazma becerisinin gelişimini farklı şekillerde desteklemektedir. Bu noktada Web 2.0 araçlarının genel özelliklerine ve yazma becerisine yönelik etkilerine değinmek yerinde olacaktır.

\section{Yazma Uygulamalarında Web 2.0 Araçları}

Web 2.0 hizmetlerinin temel amacı, kullanıcıların içerik paylaşmalarını ve aynı zamanda İnternet'in sosyal etkileşim ve işbirliği potansiyellerinden yararlanmasını sağlamaktır (Horzum, 2010). Arslan (2009), Web teknolojisinin sağladığı bilgi paylaşım ortamında öğrencinin, hem kendi çalışmasını hem de diğer öğrencilerin çalışmalarını değerlendirip kendi çalışmalarının güçlü ve zayıf yönlerini görme olanağına sahip olacağını, böylece kendine dair farkındalığının artacağını belirtmektedir. İnce (2011), Web. 2.0 araçları sayesinde öğretmen ve öğrencilerin ihtiyaç duyduğu çevrim içi iletişim ve bilgi paylaşımını kolayca sağlayabileceklerini ifade etmektedir. Önal, Kaya ve Draman (2006), Web 2.0 araçlarıla daha etkin bir eğitim ve hizmetin alınabilmesi için geniş bilgiye hızlı, kolay ve düzenli ulaşılması gerektiğini; kullanıcı ve sistem arasında etkileşimin yüksek düzeyde olması gerektiğini belirtmektedir.

Google Drive, Google Docs, E-mail, Facebook, Whatsapp, Twitter, Wiki, Blog gibi Web 2.0 araçları yazma becerisine yönelik olarak kullanılabilmektedir. Bu Web 2.0 araçları yazma becerilerini geliştirmekte, yazılı ürünlerin hitap ettiği kitleyi genişletmekte, yazmaya 
yönelik motivasyonu arttırmakta, düşünceleri geliştirmekte ve özgürleştirmekte, sözcük seçiminde yardımcı olmakta, paragraf gibi metin yapılarını fark edilmesini sağlamakta, yazılı ürünlerin yayınlanmasına karşı olumsuz görüşü değiştirmekte, işbirliğine dayalı yazma firsatı vermekte, üyeleri birbirinden uzakta olan grup çalışmalarına firsat vermekte, akran desteğini arttırmakta, yazmaya ve yaratıcılığa ilham vermekte, kişisel düşünceleri ve duyguları aktarmaya imkan vermekte, hobi ve deneyimlerin yansıtılmasını sağlamakta, tartışma ortamı sunmaktadır (Ajjan ve Hartshorne, 2008; Alexander, 2006; Alsaleem, 2013; Bennett, Bishop, Dalgarno, Waycott ve Kennedy 2012; Brodahl, Hadjerrouit ve Hansen, 2011; Duffy, 2008; Fattah, 2015; Grosseck ve Holotescu, 2008; Grosseck, 2009; İnce ve Akdemir, 2013; Kalelioğlu ve Gülbahar, 2010; Özmen, Aküzüm, Sünkür ve Baysal 2011; Shih, 2011; Sofia, 2015; Thompson, 2007).

\section{Web 2.0 Aracu Poll Everywhere}

Yukarıda bahsedilen Web 2.0 araçlarından biri olan ve çalışmanın odak noktasını oluşturan Poll Everywhere; çoklu seçenek, kelime bulutu, sorular-cevaplar, sıralama, tıklanabilir resim, anket ve açık uçlu sorular olmak üzere yedi bölümden oluşmaktadır. Uygulamanın çalışma esası, öğrencinin cep telefonu ya da bilgisayar aracılığıyla belirlenen sorulara cevap vermesine dayanmaktadır. Bu cevaplama sistemi; Whatsapp ve Facebook Messenger mesaj sistemine ve cep telefonlarının kısa mesaj sistemine benzemektedir. Öğrenciler, uygulayıcıya göre özelleştirilmiş (pollev.com/kullanıcı) uzantıya İnternet üzerinden girerek aktif olan soru havuzlarını görüp mesaj gönderebilmektedir. Gönderilen her mesaj, anlık olarak anonim bir şekilde cevap havuzunda görülebilmektedir. Uygulayıcı aktif soruları değiştirdiğinde, öğrencilerin herhangi bir işlem yapmasına gerek kalmaksızın ekranlarındaki sorular da değişmektedir. Uygulama, ders içinde gerçekleşiyorsa uygulayıcının soru ve cevap havuzunu yansıtıcı yardımıyla öğrencilere göstermesi uygulamanın daha kolay ve etkili kullanılmasını sağlamaktadır.

Bu çalışmada, Poll Everywhere Web 2.0 aracına ve bu Web 2.0 aracı için hazırlanan yazma etkinliklerine yönelik öğrenci görüşlerinin alınması amaçlanmış ve bu amaca yönelik olarak aşağıdaki sorulara yanıt aranmıştır.

1. Öğrencilerin Poll Everywhere Web 2.0 aracına yönelik düşünceleri nasıldır?

2. Öğrencilerin hazırlanan etkinliklere yönelik düşünceleri nasıldır?

\section{Yöntem}

Araştırmada, durum çalışması desenlerinden "iç içe geçmiş tek durum" deseni kullanılmıştır. Bu desende bir durum içinde birden fazla alt tabaka ya da birim bulunmaktadır (Yıldırım ve Şimşek, 2013, s. 327). Araştırmada Poll Everywhere Web 2.0 aracının yazma becerisinde kullanımına yönelik öğrenci görüşleri tek durum olarak ele alınmıştır. Alt tabakaları ise Poll Everywhere Web 2.0 aracına yönelik öğrenci görüşleri ve bu Web 2.0 aracı için hazırlanan yazma etkinliklerine yönelik öğrenci görüşleri oluşturmaktadır.

\section{Çalışma Grubu}

$\mathrm{Bu}$ araştırmanın çalışma grubunu, Yıldız Teknik Üniversitesi TÖMER bünyesinde B1 seviyesinde eğitim almakta olan ve kolay ulaşabilir durum örneklemesi yöntemiyle seçilen 5'1 kız 5'i erkek olmak üzere 10 öğrenci oluşturmaktadır. Kolay ulaşabilir durum örneklemesinde araştırmacı, yakın olan ve erişilmesi kolay bir örneklem grubunu seçer (Yıldırım ve Şimşek; 2013). Bu çalışmanın araştırmacılarından biri örneklem grubunun öğretmenliğini yaptığı için kolay ulaşabilir durum örneklemesi tercih edilmiştir.

\section{Veri Toplama Araçları}

Poll Everywhere uygulaması, doğrudan yazma çalışmaları için geliştirilmiş bir Web 2.0 aracı değildir. Fakat yazma çalışmalarında alternatif olarak kullanılması mümkündür. Araştırma kapsamında hazırlanan etkinlikler, Poll Everywhere Web 2.0 aracının üç bölümünde hazırlanmıştır. Kelime Bulutu bölümü, yazmaya hazırlık sürecinde düşünceyi geliştirme amacıyla öğrencilerin kavram ya da çağrışım alanlarını tespit etmeye yönelik tercih edilmiştir. 
Soru-cevap ve açık uçlu soru bölümleri, cümle ve paragraf düzeyindeki yazma çalışmalarında kullanılmıştır. Soru-cevap bölümünün, içerdiği puanlama sistemi sebebiyle (puanlama-sıralama) grup değerlendirmesine uygun olacağı düşünülmüştür.

Poll Everwhere Web 2.0 aracı öğrenciye hızlı ve anlık olarak cevap verme olanağı, etkili bir şekilde iletişim hâlinde olma firsatı ve sınıf arkadaşlarının cevaplarından yararlanabilme imkânı sağlamaktadır. Bu sebeple Poll Everywhere Web 2.0 aracı için kelime, cümle ve paragraf düzeyinde iletişimsel yaklaşım göz önüne alınarak üç adet etkinlik hazırlanmıştır. Bu tip etkinliklerin Poll Everywhere'in sunduğu imkânları tamamlar nitelikte olacağı varsayılmıştır.

Hazırlanan etkinliklerde, öğrencilerden herhangi bir bilgiyi aktarması beklenilmemiş ve herhangi bir bilginin aktarımı ölçülmemiştir. Aynı zamanda etkinlik ürünleri doğru ya da yanlış şeklinde değerlendirilmemiştir. Etkinliklerde öğrencilerin var olan fikirlerini yansıtması, belirli durumlar hakkında yorumlar getirmesi, değerlendirmeler yapması ve yaratıc1lıklarını kullanması amaçlanmıştır. Çalışma iletişimsel yaklaşım temelinde gerçekleştiği için öğrencilerin dil bilgisi yapılarını kullanma durumunun değerlendirmeye alınmaması tercih edilmiştir. Etkinlik yönergelerinde ve etkinlik sorularında kullanılan dil bilgisi yapılarında ise, hedef kitlenin mevcut dil seviyesine dikkat edilmiştir.

Etkinlik konuları, öğrencilerin derslerinde kullandığı Yedi İklim Türkçe B1 Ders Kitabı'ndaki temalardan seçilmiştir. Etkinlik konularının öğrencilerin rahatça katılabileceği ve fikrini en doğal hâli ile ifade edebileceği bir şekilde, güncel ve eğlenceli olması amaçlanarak etkinliklerde işlenmesine özen gösterilmiştir. Etkinliklerde öğrencilerin aktif olması ve iletişim kurması esastır. Bu sebeple etkinlikler, grup çalışmasına uygun olacak şekilde hazırlanmıştır. Bireysel çalışmalarda, yazısını önce bitirip cevap havuzuna gönderen öğrencilerin fikirlerinin, yazma sürecindeki öğrencilere yardımcı olabileceği düşünülmüştür. Yazma süreci sona erdikten sonra öğrencilerden tüm yazılı ürünleri değerlendirmesi beklenilmiştir. $\mathrm{Bu}$ amaçla Poll Eveywhere'nin sorular-cevaplar bölümündeki puanlama/sıralama tuşları ya da sözlü dönütler kullanılmıştır. Grup değerlendirmesi aracılığıyla her bir öğrenci tarafından ortaya konulan yazıların bir okurunun olması, böylece değerlendirme sürecinde öğretmen-öğrenci ikileminin aşılacağı düşünülmüştür.

Uygulamaya geçilmeden önce öğrencilerin ders kitabından işlemiş olduğu temalardan belirlenip oluşturulmuş üç etkinlik (Sosyal Medya, Kitap Kurdu ve Hangi Film?) (Ek 1.) öğrencilere sunulmuştur. Üç etkinlikteki tüm sorular yazılı bir şekilde toplam altı ders saati olmak üzere iki günde cevaplanmıştır. Bu süreçte uygulanan etkinliklerde öğrencilerden ya sözel olarak cevap havuzundaki yazıları yorumlamaları istenmiş ya da Poll Everywhere üzerinden yazılara yönelik puanlama yapmaları beklenmiştir. Ayrıca öğrencilerin bir yargıya yönelik olarak argüman üreteceği ya da hikâye yazacağı etkinliklerde grup çalışması yapmalarına imkân verilmiştir.

Etkinlik sürecinin sonunda öğrencilerin Poll Everywhere Web 2.0 aracına ve hazırlanan etkinliklere yönelik düşüncelerini tespit etmek amacıyla araştırmacılar tarafından çalışmanın amacına uygun şekilde Poll Everywhere'in "Anket" bölümünde beş tanesi Poll Everywhere uygulamasına, beş tanesi ise hazırlanan etkinliklere yönelik olmak üzere toplam on adet açık uçlu sorudan oluşan "Yarı Yapılandırılmış Görüşme Formu" hazırlanmıştır. Görüşme formunun niteliğinin ve kapsamının ölçülmesi için alan uzmanlarının fikri alınmış ve dönütler doğrultusunda soru formuna son hâli verilmiştir. Oluşturulan yarı yapılandırılmış görüşme formu tek bölümden oluşmaktadır. Formda öğrencilerin kişisel bilgilerine yer verilmemiştir.

\section{Verilerin Analizi}

Görüşme sorularından elde edilen verilerin çözümlenmesinde içerik analizine başvurulmuştur. İçerik analizi, benzer verileri belirli kavramlar ve temalar çerçevesinde bir araya getirmek, düzenlemek ve yorumlamaktır (Yıldırım ve Şimşek, 2013, s. 259). Elde edilen verilerin içerik analizine tabi tutulması sonucunda veriler, Poll Everwhere Web 2.0 aracina ve hazırlanan etkinliklere yönelik bulgular olmak üzere iki kategori altında değerlendirilmiştir. Bu kategorilerin altındaki bulgular, anahtar ifadeler şeklinde frekanslarıyla birlikte sunulmuştur. 
Anahtar ifadelerin detaylı bir şekilde çözümlenmesinde, öğrencilerin o anahtar ifadeye yönelik ortak görüşlerinden faydanılmıştır. Öğrenci görüşleri ise hem yorumlanarak hem de doğrudan alıntılanarak sunulmuştur.

\section{İnandırıcılık ve Aktarılabilirlik}

Araştırmadaki veri araçlarının geçerli ve güvenirliği açısından geliştirilen etkinlikler birden fazla alan uzmanı tarafından yapılandırılmıştır. Görüşme formlarında yer alan sorular, alan uzmanlarının görüşleri doğrultusunda oluşturulmuştur. Uygulamada kullanılan etkinlik içerikleri öğrencilerin tamamlamış olduğu temalar gözetilerek belirlenmiştir. $\mathrm{Bu}$ durum çalışmanın inandırıcılık yönünü güçlendirmiştir. Araştırmadaki verilerin aktarılabilir olması amacıyla etkinlik içerikleri hedef kitlenin ders materyallerinden seçilmiştir.

\section{Bulgular}

Öğrencilerin Poll Everywhere Web 2.0 aracına ve hazırlanan etkinliklere yönelik oluşturulmuş sorulara vermiş oldukları yanıtlar doğrultusunda elde edilen bulgular ve yorum aşağıda sunulmuştur.

\section{Poll Everywhere Web 2.0 Aracina Yönelik Bulgular ve Yorum}

Etkinlikler uygulandıktan sonra Poll Everywhere Web 2.0 aracını değerlendirmek üzere öğrencilere ilk olarak "Sizce Poll Everywhere nasil bir uygulamadır?" sorusu yöneltilmiştir. On öğrencinin tamamı, birden çok anahtar ifadelerle beraber açıklamalarda bulunmuştur. Verilen cevaplar incelendiğinde ĕglenceli, kolay, faydall, güzel, ilginç, etkili, heyecanll, orijinal, hızl, farkl, tekrarlayan şeklinde anahtar ifadelere ulaşılmıştır. Sadece tekrarlayan şeklinde bir sıfat kullanan bir öğrenci, olumsuz görüş bildirmiştir. Bu durumun sebebi olarak Poll Everywhere Web 2.0 aracının yazmaya imkân tanıyan yalnızca üç bölümünün (kelime bulutu, soru cevap, açık uçlu soru) oluşu, tüm yazma etkinliklerinin bu üç bölüm üzerinde yapılması gösterilebilir. Olumlu anahtar kelimeler arasında ise ĕglenceli, kolay, faydalı ve güzel ifadeleri öne çıkmıştır. Öğrenci açıklamalarına göre Poll Everywhere aracının orijinal, farklı ve ilginç olması, geleneksel yazma materyallerine alternatif olmasıyla açıklanmaktadır. Web 2.0 aracının hizlı olması, ögrencilerin verdiği anlık cevapların anında cevap havuzunda gözükmesiyle ortaya çıkmaktadır. Kolay olması, öğrencilerin Web 2.0 aracına telefonlarıyla rahat bir şekilde erişmesinden, basit bir kutucuğa cevaplarını hızlıca yazmasından kaynaklanmaktır. Güzel, heyecanl ve eğlenceli olması, Web 2.0 aracının Messenger ve Whatsapp mesajlaşma sistemine benzemesiyle ilgilidir. Faydalı ve etkili olması ise öğrencilerin Web 2.0 aracını yalnızca bir eğlence olarak değil aynı zamanda verim alınan bir eğitim ortamı olarak görmesinden kaynaklanmaktadır.

Poll Everywhere Web 2.0 aracını değerlendirmek üzere öğrencilere ikinci olarak "Poll Everywhere uygulamasının hangi özelliklerini beğendiniz?" sorusu yöneltilmiştir. On öğrencinin tamamı hoşlandığı özellikleri açıklamıştır. Yedi öğrenci tarafindan dile getirilen interaktiflik özelliği öne çıkmıştır. Bu özelliği bazı öğrenciler "interaktif bilgi alışverişi sağlar, interaktif özellik hoşuma gitti, sınıfı daha interaktif yaptı" şeklinde açıklamalarda ortaya koymuştur. Beş öğrenci tarafından ifade edilen yazılı ürünlerin herkese açık olması özelliği öne çıkan bir diğer özelliktir. Etkileşimli sınıf ortamıyla yakından ilişkisi olan bu özelliği, öğrenciler "herkesin cevaplarını görebiliriz, arkadaşımın düşüncesini anlarım, cevaplar görünür, gizli cevap yoktur" şeklinde açıklamıştır. Ayrıca yazılı ürünlerin herkese açık olması ile yakından ilişkisi olan ve dört öğrenci tarafından arkadaş fikirlerinden yararlanmak şeklinde başka bir özellik de dile getirilmiştir. Öğrenciler bu özelliği "başka yazılara yardımcı olur, ortak hikâye yazarız, düşünceler gizli kalmaz" gibi ifadelerle desteklemiştir. Arkadaş fikirlerinden yararlanmanın yanında arkadaşlarla beraber ortak değerlendirme yapmaya da dört öğrenci değinmiştir. Bu görüş puan vermek ve birinci seçmek, yarışma yapmak, başkasının hatasını bulmak, bulunan hatayl düzeltmek gibi anahtar ifadelerle desteklenmiştir. Bu bulgular haricinde dijital ortamda yazma imkânı sağlaması, geleneksel yazma materyallerinden daha kolay kullanılması, tek bir sayfaya tüm öğrencilerin yazılarının sığması, ders kitabına alternatif 
olması, kelime öğrenmek için uygun olması Poll Everywhere'in hoşlanılan diğer özellikleri olarak siralanmaktadir.

Poll Everywhere Web 2.0 aracını değerlendirmek üzere öğrencilere üçüncü olarak "Poll Everywhere uygulamasının hangi özelliklerini beğenmediniz?" sorusu yöneltilmiştir. Bu soruya iki öğrenci olumsuz yanıt vermiş, diğer öğrenciler "sorun yok, hiç, hepsini sevdim, güzel site" şeklinde ifadelerle memnuniyetlerini ifade etmişlerdir. Poll Everywhere'in kısa ya da uzun fark etmeksizin hep bir kutucuğa yazma özelliği hakkında olumsuz düşüncesi olan bir öğrenci "Yazma tekrar ediyor, hep aynı kutu." ifadeleriyle eleştiride bulunmuştur. Bir diğer öğrenci ise Poll Everywhere'in çoğunlukla metin tabanlı bir yapı sergilemesini "Fotoğraf ve sanat yok. Daha renkli olmalı." cümleleriyle eleştirmiştir.

Poll Everywhere Web 2.0 aracını değerlendirmek üzere öğrencilere dördüncü olarak "Poll Everywhere uygulaması yazma isteğinizi arttırdı mı? Neden?" sorusu yöneltilmiştir. On öğrencinin tamamı "evet, kesinlikle, artt1, çok, tabii" gibi anahtar ifadelerle olumlu görüş bildirmiştir. Yazmaya yönelik motivasyonun ne şekilde arttığına dair verilen cevaplar incelendiğinde bir takım bulgulara ulaşılmıştır. Aracın dört öğrenci tarafından tekrar edilen gizli kimlik özelliği, yazma isteğini arttıran öncelikli etkenlerden biri olarak gözükmektedir. Öğrenciler, istediği takdirde kimliği gizli bir şekilde cevap verebilmesi sayesinde heyecan, stres, yanlış yapmaktan korkma gibi negatif duygulara kapılmamaktadır. Bu durum "Arkadaşlarım ve öğretmenim benim yazıyı bilmez. Rahat yazıyorum", "Hatadan korkmuyorum. Çünkü herkes okuyor, beni tanımıyor." vb. ifadelerle desteklenmiştir. Değerlendirme ve puanlama/sıralama sisteminin yazma isteğine yönelik olumlu etkisi başarı için çalışmak, birinci olmanın güzel olması, hatalar hakkında dönüt almak, yanlışların düzeltilmesi anahtar ifadeleriyle dört öğrenci tarafından ortaya konmuştur. Öğrencilerin üçüne göre aracın doğal bir şekilde yazma özelliği, yazma isteğini arttıran bir durumdur. Elde edilen bulgulara göre doğal bir şekilde yazma günlük telefon kullanımının derse yansıması şeklinde kendini göstermiştir. Bu durumu öğrencilerden biri "Sanki arkadaşıma mesaj atıyorum." şeklinde ifade etmiştir. Ayrıca yazma etkinliklerine konu ile ilgili basit fotoğraf ya da resimlerin eklenebilmesi üç öğrenci tarafından ilham verici olarak belirtilmiştir.

Poll Everywhere Web 2.0 aracını değerlendirmek üzere öğrencilere beşinci olarak "Poll Everywhere uygulamasını sonraki derslerinizde kullanmak ister misiniz? Neden?" sorusu sorulmuştur. On öğrencinin tamamı "kesinlikle, evet, isterim" şeklinde olumlu görüş bildirmiştir. Ancak üç öğrencinin olumlu görüşlerine uyarı niteliğinde eklemeler yapması dikkat çekicidir. Bu duruma ilişkin öğrencilerden biri "Biraz ders kitabı (kitap konularını kaçırmamak için), biraz Poll Everywhere (uzun derslerde sıkılmamak için)" şeklinde ifadelerle bulduğu çözüm yolunu açıklamıştır. Bu Web 2.0 aracının sürekli kullanımının yaratacağı soruna ilişkin ifadeler "hep kullanılırsa, ders kitabı gibi olur", "sürekli kullanmayalım, bir özelliği kalmaz" şeklindedir. Bir öğrenci ise "Yazma ödevi bu olsun. Ders dışında çok güzel olur." şeklinde uygulamanın ev ödevi olarak da kullanılmasına değinmiştir. Genel olarak ise öğrenciler; eğlenme, rahatlama, hikâye yazma, düşüncelerini paylaşma, ilginç konular hakkında yazma gibi durumlarda Web 2.0 aracını her ders kullanmak istemektedir. Fakat önceden de belirtildiği gibi tüm yazma çalışmalarının bu uygulama üzerinden yürütülmesinin sınırlılıklar yaratacağı da düşünülmektedir.

\section{Etkinliklere Yönelik Bulgular ve Yorum}

Poll Everywhere Web 2.0 aracı için hazırlanmış etkinlikleri değerlendirmek üzere öğrencilere ilk olarak "Etkinlikler hakkında ne düşünüyorsunuz?" sorusu yöneltilmiştir. On öğrencinin tamamı görüş bildirmiştir. Öğrenciler etkinlikler hakkındaki düşüncelerini uygun, güzel, ilginç, güncel, faydall, kolay, ĕglenceli, bilgilendirici anahtar ifadeleriyle açıklamıştır. Buna göre etkinliklerin eğlenceli, güzel, kolay, uygun, faydalı oluşu ön plana çıkmaktadır. Ĕglenceli kavramının altında yatan odak nokta; etkinliklerin yapılması zorunlu yazma materyalleri olarak görülmemesi, yazılan yazılardan net bir bilginin beklenmemesi, yaratıcılığa ve kişisel düşüncelere firsat verilmesidir. Kolay kavramı, etkinlik soruları veya etkinlik yönergelerinin kavrama ve dilbilgisi yapıları açısından öğrencilerin dil seviyesine olan denkliğiyle; uygunluk 
kavramı, yazma becerisi açısından öğrencilerin ilgisini çeken ve üzerine rahatça fikir beyan edilebilecek etkinlik konularının bulunmasıyla; faydalı ve bilgilendirici kavramları, etkinliklerin öğrencilerin yeni bilgiler edinmesine fursat vermesiyle; güncel kavramı, etkinlik konu ve içeriklerinin günlük hayatta karşılığının olmasıyla; ilginç kavramı, daha önce içerik ve teknik açısından bu tarz etkinliklerle karşılaşılmamasıyla; güzel kavramı ise, etkinliklerin kişisel zevklere hitap etmesiyle açıklanabilir.

Poll Everywhere Web 2.0 aracı için hazırlanmış etkinlikleri değerlendirmek üzere öğrencilere ikinci olarak "Sizce en güzel yazma etkinliği hangisi? Neden?" sorusu yöneltilmiştir. On öğrencinin tamamı bu soru hakkında görüş bildirmiştir. Üç öğrenci düşüncelerini "Tüm etkinlikler güzel fark yok. Yazma etkinliklerini beğendim. Hepsini sevdim." şeklinde ifade etmiş ve etkinliklerin karşılaştırma yapmaksızın beğenilerine hitap ettiğini açıklamışlardır. Ayrıca bu düşünceler "Etkinlikler farklı ve çeşitli, etkinlikleri genel hayatta kullanıyoruz." ifadeleriyle desteklenmiştir. Bir öğrenci kitap okumayı ve kitaplar hakkında konuşmayı çok sevdiği için en güzel etkinliğin "Kitap Kurdu" adlı etkinlik olduğunu ifade etmiştir. Başka bir öğrenci, yaratıcılığını arttırdığını düşündüğü için en çok "Hangi Film?" etkinliğini beğendiğini söylemiştir. Beş öğrenci ise en çok "Sosyal Medya" etkinliğini beğendiğini ifade etmiştir. Bu görüşlerde öne çıkan detaylar ilgili etkinliklerin kapsamının geniş olması, gerçek hayatla ilişkili olması, bilgilendirici olması, güncel olması, gençlerin hayatıyla ilgili olması ve iletişim konusunu içermesi şeklinde ç̧şitlenmiştir.

Poll Everywhere Web 2.0 aracı için hazırlanmış etkinlikleri değerlendirmek üzere öğrencilere üçüncü olarak "Beğenmediğiniz bir etkinlik var mı? Neden?" sorusu yöneltilmiştir. Bu soruda iki öğrenci olumsuz görüss bildirirken sekiz öğrenci "Hayır, yok, hepsi iyi, sorun yok." şeklinde ifadelerle memnuniyetlerini ifade etmişlerdir. Olumsuz görüş bildiren öğrenciler ise etkinliklerin kendisinden çok etkinlik içindeki sorularla problem yaşadıklarını belirtmişlerdir. Örneğin bir öğrenci "Sosyal Medya" etkinliğindeki "Sosyal medya uygulaması yaratma" bölümünün uzun bir zaman üzerinde düşünülerek yapılması gerektiğini ve zor olduğunu ifade etmiştir. Başka bir öğrenci ise "Bazı sorular kültür bilgisi istiyor." şeklinde genel kültür seviyesinin kendisi için birkaç soruda problem yarattığını belirtmiştir.

Poll Everywhere Web 2.0 aracı için hazırlanmış etkinlikleri değerlendirmek üzere öğrencilere dördüncü olarak "Poll Everywhere'deki etkinlikler ile ders kitabınızdaki etkinlikler arasında fark var mı? Nasıl?" şeklinde soru yöneltilmiştir. Buna göre on öğrencinin tamamı yanıtlarında Web 2.0 aracında uygulanan etkinliklerin lehine olan farklılıklardan bahsetmiştir. Ancak bu on öğrencinin üçü, ders kitabındaki etkinliklerin de lehine bir farklılığa değinmiştir. Ayrıca bu üç öğrencinin dışında kalan başka bir üç öğrenci, "biraz benziyor, çok büyük fark yok, eşit gibi" anahtar ifadeleriyle etkinliklere yönelik farklılıkları bulmakta zorluk çektiklerini de belirtmiştir. Web 2.0 aracına yönelik hazırlanan etkinliklerin lehine oluşan farklılıklar ilginç, çeşitli, farklı ve güncel olması, basit ve kolay bir şekilde yapılması, konuların bağımsız olması, etkinliklerin kapsamlarının geniş olması, öğrenci özerkliğine olanak tanıması şeklinde çeşitlenmiş̧ir. Bu farklılıklardan ilginç ve farklı kavramları, daha önce de değinildiği gibi öğrencilerin bu tip konu ve etkinliklerle karşılaşmadığını göstermektedir. Çeşitli kavramı konu ve etkinliklerin farklı ve bol olduğuna işaret etmektedir. Güncel kavramı, günlük hayatla daha ilişki olmasını belirtmektedir. Basit ve kolay kavramları etkinlik yönergelerinin/sorularının rahatlıkla anlaşıldığını ve bu doğrultuda kolayca yazılar yazılabildiğini, etkinliklerin hedef kitlenin dil seviyelerini aşmadığını göstermektedir. Konuların bağımsız olması, etkinliklerin uygulanabilmesinin çoğunlukla başka metinlere ya da materyallere bağlı olmadığını belirtmektedir. Etkinliklerin kapsamlarının geniş olmasl, bir konunun daha derinlemesine ve çeşitli açılardan incelendiğini ifade etmektedir. Öğrenci özerkliğine olanak tanımast; bireyselleşmiş yazma sürecine imkân tanımasına, yani öğrencinin nasıl isterse o şekilde yazmasına firsat vermesine işaret etmektedir. Ders kitabındaki yazma çalışmalarının lehine oluşan farklılık ise; ders kitabındaki yazma çalışmalarının Web 2.0 aracına yönelik hazırlanmış etkinliklerin aksine metin düzeyinde uzun yazılara firsat vermesiyle açıklanmaktadır.

Poll Everywhere Web 2.0 aracı için hazırlanmış etkinlikleri değerlendirmek üzere öğrencilere beşinci olarak "Poll Everywhere'deki etkinlikler size katkı sağladı mı? Nasıl?" 
sorusu yöneltilmiștir. On öğrencinin dokuzu "Evet, muhakkak, çok, tabii" anahtar ifadeleriyle tamamen olumlu bir dönütte bulunurken, bir öğrenci eğlenceli vakit geçirme anahtar ifadesiyle "biraz" şeklinde kısmen olumlu olan düşüncesini ifade etmiştir. Buna göre etkinliklerin, dört öğrencinin belirttiği üzere yaratıcı yazma iki öğrencinin belirttiği üzere eleştirel yazma becerisinin gelişiminde katkı sağladığı görülmektedir. Yaratıcı yazma becerisine yönelik destekleyici ifadeler öz olarak konuların ilginç olması, soruların düşündürücü olmasl, ciddi ve komik etkinlikler sayesinde farkl sebeplerle yazma, hikâye yazma etkinliklerinin olması şeklinde çeşitlenmiştir. Eleştirel yazma becerisine yönelik destekleyici ifadeler ise öğrencilerin bazı etkinlik sorularındaki yargı bildiren durumlara karşı kendi fikirlerini ortaya koyabilmesi ve arkadaşlarının fikirlerini değerlendirmesiyle açıklanmaktadır. Aynı zamanda öğrenci görüşlerine göre etkinliklerin yazma isteğini arttırma, grup çalısması yapma, öğrenci özerkliğine firsat verme, bilgilendirici olma hususlarında katkı sağlayıcı nitelikte olduğu bulgusuna ulaşılmıştır.

\section{Tartışma ve Sonuç}

Öğrencilerin Poll Everywhere Web 2.0 aracına ve uygulanan etkinliklere yönelik görüşlerinden elde edilen bulgular ve bulguların yorumlanması neticesinde ulaşılan tartışma ve sonuç aşağıda sunulmuştur.

\section{Poll Everywhere Web 2.0 Aracına Yönelik Tartışma ve Sonuç}

Poll Everywhere Web 2.0 aracina yönelik bulgular incelendiğinde öğrencilerin büyük çoğunluğunun Poll Everywhere'den hoşlandığı ve bu Web 2.0 aracının özelliklerine yönelik olumlu görüşler bildirdiği sonucuna ulaşılmaktadır.

Araştırmaya katılan öğrenciler tarafindan Poll Everywhere eğlenceli, kolay, faydall, güzel, ilginç, etkili, heyecanl, orijinal, hızl, farkl, tekrarlayan şeklinde yüksek oranda olumlu sıfatlarla tanımlanmıştır. Bu araştırmanın bulgularını destekleyecek şekilde Warnich ve Gordon (2015), çalışmasında öğrencilerin Poll Everywhere'e yönelik pozitif algılarının olduğunu ve bu Web 2.0 aracının sınıfi daha hızlı, ilginç ve eğlenceli hâle getirdiğini belirtmektedir. Ayrıca Eva ve Nicholson (2011) Poll Everywhere'in öğrencilerin ilgisini çekmenin popüler ve eğlenceli bir yolu olduğuna değinmektedir. Shon ve Smith (2011) ise bu Web 2.0 aracının eğlenceli olduğunu ve kolay bir şekilde kullanıldığını belirtmektedir. Bunların haricinde ilgili araştırmaların bazılarında Poll Everywhere'in eğlenceli olduğuna yönelik bulgulara ulaşmak mümkündür (Kappers ve Cutler, 2015; Noel, Stover ve McNutt, 2015). Öğrenci cevapları ve ilgili araştırmalar incelendiğinde Poll Everywhere'in eğlenceli, hızlı ve kolay oluşunun ön plana çıktığı söylenebilir. Poll Everywhere Web 2.0 aracının teknoloji ve İnternet tabanlı bir oluşum sergilemesi neticesinde, öğrencilerin günlük hayatlarında kullandığ 1 sanal mesajlaşma sistemlerine benzemesi bu durumun sebebi olarak gösterilebilir. Ayrıca bulgular kısmında yorumlanan güzel ve heyecanlı kavramları da bu durumu destekler niteliktedir. Poll Everywhere, sadece kullanım özellikleri açısından tanımlanmamaktadır. Ayrıca Poll Everywhere'in orijinal, farklı ve ilginç olması sebebiyle geleneksel yazma materyallerinin alternatifi olarak; faydalı ve etkili olması sebebiyle verim alınan bir eğitim ortamı olarak görülmesi bu Web 2.0 aracının eğitimsel amaçlarla da ön plana çıktığını göstermektedir. Araştırmada ulaşılan bu sonucu destekler şekilde Warnich ve Gordon (2015), Poll Everywhere'in yalnızca bir eğlence aracı olarak değil, geleneksel öğretim ve öğrenme için ek bir araç olarak da düşünülmesi gerektiğini vurgulamıştır.

Öğrenci görüsslerine göre Poll Everywhere Web 2.0 aracı interaktif/etkileşimli bir sınıf ortamı oluşturmaktadır. Bir çok ilgili çalışmada, ulaşılan bu sonucu destekler şekilde Poll Everywhere Web 2.0 aracının derse katılımı arttırdığı, öğrenciler arası iletişimi olumlu şekilde etkilediği, grup çalışmaları açısından verimli olduğuna değinilmektedir (Achen ve Lumpkin, 2015; Eva ve Nicholson; 2011; Kappers ve Cutler, 2015; Noel, Stover ve McNutt; 2015; Shon ve Smith, 2011; Sikarwar, 2015). Öğrencilerin yazılı ürünlerinin herkese açık bir şekilde sergilenmesi ve bu yolla ögrencilerin birbirlerinin fikirlerinden ve yazılı ürünlerinden faydalanması Poll Everywhere'in interaktif/etkileşimli bir sınıf ortamı oluşturduğunun iki önemli göstergesidir. Ayrıca öğrenciler, bu Web 2.0 aracıyla grup değerlendirmesi 
yapabilmelerine dikkat çekmişlerdir. Öğrenciler grup değerlendirmesini ise yazll hataları fark etmek ve yazılı ürünlere puan vermek olarak iki şekilde ele almaktadırlar. Bu noktada, öğrencilerin başkalarının hatalarını fark ederek, kendi hatalarına ilişkin dönütler alarak, en iyi yazılı ürünü seçmek için puanlama yaparak nitelikli bir şekilde değerlendirme yaptıklarını söylemek mümkündür. Araştırmada ulaşılan bu sonucu destekler şekilde Warnich ve Gordon (2015), Poll Everywhere aracılığıyla cevap havuzundaki farklı cevapların değerlendirilmesinin dönüt vermeyi ve eleştirel düşünmeyi geliştirdiğini, değerlendirme yapmayı desteklediğini belirtmektedir. Ayrıca değerlendirme sürecine yönelik olarak Noel, Stover ve McNutt (2015) Poll Everywhere'in sınıftaki tartışmaların kalitesini arttırdığını, Shon ve Smith (2011) karar vermeyi demokratik bir şekilde kolaylaştırdığını, Sikarwar (2015) ise zamanında geri bildirim almayı sağladığını ifade etmektedir.

Poll Everywhere Web 2.0 aracı birçok yönden avantajlı olmasına rağmen bazı kısıtlı özelliklere de sahiptir. Yazma becerisine yönelik Poll Everywhere bölümlerinin yetersiz kaldığ noktalar bulunmaktadır. Poll Everywhere'de mesaj kutusuna yazılan yazılar haricinde çeşitli yazı yazma yöntem ve tekniklerine uygun bölümler bulunmamaktadır. İlgili bazı çalışmalara bakıldığında Poll Everywhere'in çevirim içi anket/sınav uygulamasında kullanılacak bir Web 2.0 aracı kategorisi altında ele alındığı görülmektedir (Altık, Yükseltürk ve Üçgül, 2017; Elmas ve Geban, 2012). Poll Everywhere'in yazma becerisine yönelik bir Web 2.0 arac1 kategorisine alınması tam anlamıyla mümkün olmasa da öğrencilerin hemen hemen hepsinin yazma becerisine yönelik bu Web 2.0 aracını benimsediğini söylemek mümkündür. Bu noktada Poll Everywhere'in yapısına uygun şekilde ve uygun uzunlukta, öğrencileri etkileşim hâlinde tutacak yazma etkinliklerinin hazırlanması dikkat edilmesi gereken bir noktadır. Ayrıca metin tabanlı bir oluşum sergileyen Poll Everywhere'in etkinliklerde kullanılan bölümlerinin arka planına sanatsal açıdan yalnızca fotoğraf ve resim gibi görsellerin eklenmesinin yetersiz olduğunu düşünen bir öğrenci olsa da bu tür görsellerin, yazma becerisi açısından ilham verici ve yazmaya teşvik edici olduğunu belirten öğrenciler de bulunmaktadır. Bu sebeple uyarıcı olarak sunulan bu görsellerin faydalı olduğu söylenebilir.

Poll Everywhere Web 2.0 aracının sahip olduğu birçok özellik yazma isteğini arttırmaktadır. Ancak yazılı ürünlerin kim tarafından yazıldığını göstermeyen gizli kimlik özelliği ön plana çıkmaktadır. Gizli kimlik özelliğinin öğrenciler üzerinde yarattığı olumlu etkilere yönelik elde edilen bulgular, ilgili diğer çalışmalarla benzerlik göstermektedir. Buna göre Warnich ve Gordon (2015) içe dönük, rahatsız ya da utangaç hisseden öğrencilerin baskı ve dikkatli incelenme korkusundan gizli kimlik sayesinde kurtulduğunu, Eva ve Nicholson (2011) ise öğrencilerin yanlış cevap verme endişesinin gizli kimlik sayesinde ortadan kalktığını belirtmektedir. Ayrıca Noel, Stover ve Mcnutt (2015), öğrencilerin rahat hissetme noktasında ve grup tartışmalarında anonim olmaya olumlu baktıklarını ifade etmektedir.

Poll Everywhere Web 2.0 aracının devamlılık açısından her derste kullanıma uygun olduğunu söylemek mümkündür. Öncelikle öğrenci görüşlerine göre geleneksel yazma materyallerinden daha kolay kullanılması, tek bir sayfasına tüm öğrenci yazılarının sığması, ders kitabına ĕglenceli ve ilgi çekici bir alternatif olması ve kelime ögretimine uygun olması, grup çalışmalarında verimli olması" gibi hususlar, Poll Everywhere'in derslerde devamlı olarak kullanılmak istenmesinin sebebi olarak öne sürebilir. Fakat öğrencilerin bu Web 2.0 aracının bir ders sürecinde kullanımına yönelik olarak uyarıları bulunmaktadır. Bu uyarılar, tüm yazma çalışmalarının Poll Everywhere ile yapılmasının bu Web 2.0 aracını basitleştireceği ve gelenekselleştireceği üzerine şekillenmektedir. Bu sebeple Poll Everywhere'in geleneksel ders materyalleri ile beraber derse entegre edilmesi uygun olacaktır.

\section{Etkinliklere Yönelik Tartışma ve Sonuç}

Poll Everywhere Web 2.0 aracı için hazırlanmış etkinliklere yönelik bulgular incelendiğinde hemen hemen tüm öğrencilerin etkinliklere yönelik pozitif algısının olduğu sonucuna ulaşılmaktadır. Ayrıca etkinlikler, iletişimsel yaklaşım açısından okur-yazar ilişkisi, öğrenciler arası iletişim, öğrenci ilgi-istek ve ihtiyaçları, öğrenci motivasyonu, içerik açısından seviyeye 
uygunluk, etkinlikler arası ilişki, güncellik, grup çalışması, eğlenceli vakit geçirme gibi birtakım hususlarda yeterlilikler göstermektedir.

Poll Everywhere Web 2.0 aracinda uygulanan etkinlikler uygun, güzel, ilginç, güncel, faydalı, kolay, eğlenceli, bilgilendirici şeklinde tamamı olumlu sıfatlarla tanımlanmaktadır. $\mathrm{Bu}$ sıfatlardan yola çıkarak etkinliklerin öğrencilerin kişisel düşüncelerini özgürce ifade etmesine firsat verdiği, dil seviyesine uygun olduğu, ilgisini çektiği, bilgi seviyesini arttırdığı, günlük hayatıyla ilişkili olduğu, daha önce karşılaştı̆̆ etkinliklerden içerik ve teknik açısından farklılaştığı ve kişisel beğenileriyle örtüştüğü söylenebilir. Öğrencilerin yazma etkinliklerine yönelik tanımlamaları göz önüne alındığında Türkçe öğrenmek için bir arada bulunan farklı kültürlerden gelen yabanc1 öğrencilere yönelik etkinliklerin birleştirici özellik gösterdiği, etkinlik konularının ise her öğrencinin bakış açısını ortaya koyabileceği ortak ve güncel kavramlar üzerine şekillendiği, bu sebeplerden dolayı da etkinliklerin eğlenceli ve kolay bir süreç içinde yapıldığı ve süreç sonunda öğrencilere fayda sağladığı söylenebilir.

Poll Everywhere Web 2.0 aracinda uygulanan "Sosyal Medya", "Kitap Kurdu", "Hangi Film?" isimli etkinlikler genel olarak öğrenciler tarafindan beğenilse de bazı sebeplerden dolayı beğenilme durumlarında farklılıklar oluşmuştur. Buna göre "Kitap Kurdu" ve "Hangi Film?" etkinliklerinin bazı öğrenciler tarafindan en beğenilen etkinlik olarak belirtilmesinde kişisel zevkler ve kişisel algılar daha ön plandadır. Fakat "Sosyal Medya" etkinliğinin en beğenilen etkinlik olarak belirtilmesinde, bu etkinliğin geniş kapsamlı olması, öğrenci seviyesine uygun olması, iletişim becerilerini içermesi ve güncel olması gibi ortak fikirler mevcuttur. Yani öğrenciler birçok farklı fikre ortam sağlayacak, günlük hayatla ilişkili, kişiler arası etkileşime firsat tanıyacak tarzda etkinlikleri daha çok beğenmektedir. Fakat birkaç etkinlik sorusunun zor olması ve cevaplanmasının daha çok zaman gerektirmesi, öğrencilerin genel kültür seviyesini yer yer aşması etkinliklere yöneltilebilecek bir eleştiri olarak görülebilir.

Poll Everywhere Web 2.0 araciyla uygulanan etkinliklerin, ders kitabındaki yazma etkinliklerinden genel olarak daha avantajlı yönleri bulunmaktadır. Etkinliklerin lehine oluşan farklılıkların bazıları etkinliklerin ilginç, çeşitli, farklı ve güncel olması, basit ve kolay bir şekilde yapılması, kapsamının geniş olması şeklindedir. Araştırmacılar tarafından hazırlanan etkinliklerin çoğunlukla başka bir metne ya da materyale bağlı olmayışı, öğrenciye özerklik firsatı sunması olumlu karşılanan başka bir farktır. Araştırmadaki etkinlikler, Poll Everywhere'in özelliği gereği kelime, cümle ve paragraf düzeyi ile sınırlı tutulmuştur. Ancak öğrenciler bu sınırlılığı, ders kitaplarındaki uzun metin çalışmaları ile karşılaştırarak ders kitabı lehine bir fark olarak ortaya koymuştur.

Poll Everywhere Web 2.0 aracıyla uygulanan etkinlikler, yaratıcı yazma ve eleştirel yazma becerisi açısından katkı sağlayıcı niteliktedir. Etkinliklerin eleştirel yazmayı geliştirmesi, hem bir yargının lehine ya da aleyhine argüman üretme hem de başkalarının argümanını değerlendirme ile açılanabilir. Bu noktada Poll Everywhere Web 2.0 aracının puanlama sistemine sahip olması ve bu araçta tüm cevapların öğrencilere açı olması da önem kazanmaktadır. Bu durumu destekler şekilde Noel, Stover ve McNutt (2015) Poll Everywhere'in sınıf tartışmalarının kalitesini arttırdığını belirtmektedir. Etkinliklerin yaratıcı yazma açısından katkı sağlayıcı olması; etkinlik konularının, amaçlarının ve kapsamlarının farklı ve düşündürücü olmasından kaynaklanmaktadır. Ayrıca öğrenciler, görüşme formunda kendilerine daha önce yöneltilen sorulardan ve bu sorulara verdikleri cevaplardan faydalanarak etkinliklerin yazma isteğini arttırma, grup çalışması yapma, arkadaşların birbirini daha iyi tanıması, ögrenci özerkliğine firsat vermesi, bilgilendirici olma hususlarında katkı sağlayıcı olduğunu tekrar etmiştir.

Son olarak uygulanan etkinliklerin Poll Everywhere Web 2.0 aracı ile uyumlu olduğunu söylemek mümkündür. Poll Everywhere Web 2.0 aracında açık uçlu yazma bölümlerinin olması ve etkinliklerde açı uçlu soruların bulunması, öğrencilerin olumlu algılarının sebeplerinden biri olarak gösterilebilir. Poll Everywhere Web 2.0 aracı üzerinde yapılan çalışmalarda açık uçlu soruların sağladığı imkanlar üzerine elde edilen sonuçlar, bu araştırmada ulaşılan sonuçlarla örtüşmektedir. Buna göre Kapper ve Cutler (2015) Poll Everywhere'deki açık uçlu soruların avantajlı ve faydalı olduğunu, Wong (2016) açık uçlu soruların öğrencilerin karşılaştığı 
problemleri gösterdiği için kullanışlı olduğunu, Shon ve Smith (2011) ise kendi cümleleri ve kelimeleriyle cevap verdikleri için öğrencilerin ne düşündükleri veya hissettikleri konusunda açık uçlu soruların yardımcı olduğunu belirtmektedir. Hem Poll Everywhere'in hem de uygulanan etkinliklerin güzel, ilginç, faydalı, kolay, eğlenceli gibi benzer sıfatlarla tanımlanması uyumluluğun başka bir göstergesidir. Poll Everywhere'in hikâye yazma, düşünceleri paylaşma, ilginç konular hakkında yazma gibi noktalarda kullanılmak istenmesi uygulanan etkinliklerin niteliği ile doğrudan ilişkilidir. Grup çalışmasi/değerlendirmesi ve etkileşim noktasında Poll Everywhere ve uygulanan etkinlikler benzer yeterlilikler göstermektedir. Etkinliklerin rekabet etmeye teşvik edici bir içeriğinin olduğunu göstermesi açısından Poll Everywhere'deki puanlama ve siralamadan oluşan değerlendirme sisteminin öğrenciler tarafından ön plana çıkartılması önemli bir noktadır. Ayrıca hem Poll Everywhere hem de uygulanan etkinlikler yazma isteğini arttırmaktadır. Ulaşılan bu sonuçlardan yola çıkarak, aynı zamanda etkinliklerin uzunluğu hakkında öğrencilerin olumsuz görüş bildirmediği göz önüne alınarak kelime, cümle ve paragraf düzeyinde yapılan yazma çalışmalarının Poll Everywhere'in kullanım özelliklerine uygun olduğu söylenebilir.

\section{Kaynaklar}

Achen, R. M. ve Lumpkin, A. (2015). Evaluating classroom time through systematic analysis and student feedback. International Journal for the Scholarship of Teaching and Learning, 9(2), 4.

Adıyaman, A. (2011). Iletişsimsel yöntem ışı̆̆ında yazınsal bir tür olan kısa öykü ile yaratıcı çalışma biçimleri (Yayımlanmamış yüksek lisans tezi). Gazi Üniversitesi Eğitim Bilimleri Enstitüsü, Ankara.

Ajjan, H. ve Hartshorne, R. (2008). Investigating faculty decisions to adopt Web 2.0 technologies: Theory and empirical tests. The internet and higher education, 11(2), 7180.

Aktaş, T. (2005). Yabancı dil öğretiminde iletişimsel yeti. Journal of Language and Linguistic Studies, 1(1), 89-100.

Alexander, B. (2006). Web 2.0: A new wave of innovation for teaching and learning? Educause review, 41(2), 32 .

Alsaleem, B. I. A. (2013). The effect of "Whatsapp" electronic dialogue journaling on improving writing vocabulary word choice and voice of efl undergraduate Saudi students. Arab World English Journal, 4(3), 213-225.

Altıok, S., Yükseltürk, E. ve Üçgül, M. (2017). Web 2.0 eğitimine yönelik gerçekleştirilen bilimsel bir etkinliğin değerlendirilmesi: Katılıme1 görüşleri. Journal of Instructional Technologies \& Teacher Education, 6(1), 1-8.

Arslan, T. (2009). Yabancl dil olarak Almanca ögretiminde web destekli öğrenme modeli Moodle'ın kullanımı ve ögrenme sürecine etkisi -yazma becerisi bağlamında görgül bir çalışma (Yayımlanmamış yüksek lisans tezi). Mersin Üniversitesi Sosyal Bilimler Enstitüsü, Mersin.

Barın, E. (2006). Yurt dışındaki Türk çocuklarına Türkçe öğretiminde dikte ve yazılı anlatımın önemi. TDAY Belleten, 2006(1), 21-32.

Bennett, S., Bishop, A., Dalgarno, B., Waycott, J. ve Kennedy, G. (2012). Implementing Web 2.0 technologies in higher education: A collective case study. Computers \& Education, 59(2), 524-534.

Brodahl, C., Hadjerrouit, S. ve Hansen, N. K. (2011). Collaborative writing with web 2.0 technologies: Education students' perceptions. Journal of Information Technology Education: Innovations in Practice, 10, 73-103.

Duffy, P. (2008). Engaging the YouTube Google-eyed generation: Strategies for using Web 2.0 in teaching and learning. Electronic Journal of E-learning, 6(2), 119-130.

Elmas, R. ve Geban, Ö. (2012). Web 2.0 tools for 21 st century teachers. International Online Journal of Educational Sciences, 4(1), 243-254. 
Eva, N. ve Nicholson, H. (2011). Do get technical! Using technology in library instruction. Partnership: The Canadian Journal of Library and Information Practice and Research, 6(2), 1-9.

Fattah, S. F. E. S. A. (2015). The effectiveness of using Whatsapp Messenger as one of mobile learning techniques to develop students' writing skills. Journal of Education and Practice, 6(32), 115-127.

Grosseck, G. (2009). To use or not to use web 2.0 in higher education? Procedia-Social and Behavioral Sciences, 1(1), 478-482.

Grosseck, G. ve Holotescu, C. (2008). Can we use Twitter for educational activities? 4th international scientific conference, eLearning and software for education içinde Bucharest, Romania.

Hamaratlı, E. (2015). Yabancılara Türkçe ögretiminde kelime ă̆l oluşturma yönteminin ögrencilerin yazma becerisi ve motivasyonuna etkisi (Mısır örneği) (Yayımlanmamış yüksek lisans tezi). Bülent Ecevit Üniversitesi Sosyal Bilimler Enstitüsü, Zonguldak.

Horzum, M. B. (2010). Öğretmenlerin Web 2.0 araçlarından haberdarlığı, kullanım sıklıkları ve amaçlarının çeşitli değişkenler açısından incelenmesi. Uluslararası İnsan Bilimleri Dergisi, 7(1), 603-634.

Ince, M. ve Akdemir, Ö. (2013). The investigations of using web 2.0 technologies on English writing skills of students with different learning styles. Eurasian Journal of Educational Research, 53, 93-106.

İnce, M. (2011). Web 2.0 teknolojileri kullanımının farklı ögrenme stillerine sahip öğrencilerin Ingilizce yazma becerilerine etkisinin incelenmesi (Yayımlanmamış yüksek lisans tezi). Zonguldak Karaelmas Üniversitesi Sosyal Bilimler Enstitüsü, Zonguldak.

Kalelioğlu, F. ve Gülbahar, Y. (2010). Investigating the usage of blogs in educational settings from multiple intelligences perspective. The Turkish Online Journal of Educational Technology, 9(2), 132-144.

Kappers, W. M. ve Cutler, S. L. (2015). Poll Everywhere! Even in the Classroom: An Investigation into the impact of using PollEverwhere in a large-lecture classroom. Computers in Education Journal, 6(20), 21.

Kuş, A. ve Bakır, N. (2013). Yabancı dil öğretiminde beyin temelli tekniklerle yazma becerilerinin geliştirilmesi. Electronic Turkish Studies, 8(10), 395-403.

Noel, D., Stover, S. ve McNutt, M. (2015). Student perceptions of engagement using mobilebased polling as an audience response system: Implications for leadership studies. Journal of Leadership Education, 14(3), 53-69.

Önal, A., Kaya, A. ve Draman, S. E. (2006). Açık kaynak kodlu çevrimiçi eğitim yazılımları. Bilgi Teknolojileri Kongresi IV / Akademik Bilișim 2006, 9-11 Şubat 2006, Denizli, Bildiriler, içinde (s. 251-254). Denizli: Pamukkale Üniversitesi.

Özcan, M. (2015). Yabancı dil olarak Arapça konuşma becerisi öğretiminde iletişimsel yaklaşıma dayalı etkinliklerin kullanımı. 21. Yüzyllda Eğitim Ve Toplum Eğitim Bilimleri Ve Sosyal Araştırmalar Dergisi, 4(10), 153-164.

Özmen, F., Aküzüm, C., Sünkür, M. ve Baysal, N. (2011). Sosyal ağ sitelerinin eğitsel ortamlardaki işlevselliği (Functionality of social networks in educational settings). 6th International Advanced Technologies Symposium (IATS'11), 16-18 Mayls 2011, Elaziğ, Bildiriler, içinde (s. 42-47). Elazığ: Fırat Üniversitesi.

Raimes, A. (1983). Techiniques in teaching writing. Oxford: Oxford University Press.

Shih, R. C. (2011). Can Web 2.0 technology assist college students in learning English writing? Integrating Facebook and peer assessment with blended learning. Australasian Journal of Educational Technology, 27(5), 829-845.

Shon, H. ve Smith, L. (2011). A review of Poll Everywhere audience response system. Journal of Technology in Human Services, 29(3), 236-245.

Sikarwar, A. S. (2015). Flipped classroom with Poll Everywhere: engaging students with active learning in large group settings. Journal of Asian Scientific Research, 5(2), 111-119. 
Sofia, H. (2015). Teaching technical writing skills using Web 2.0 technology -an experimental study (Unpublished doctoral dissertation). B.S. Abdur Rahman University İnstitute of Science and Technology, İndia.

Thompson, J. (2007). Is Education 1.0 ready for Web 2.0 students? Innovate: Journal of Online Education, 3(4), 1-6.

Ülper, H. (2008). Bilişsel süreç modeline göre hazırlanan yazma ögretimi programının öğrenci başarısına etkisi (Yayımlanmamış doktora tezi). Ankara Üniversitesi Sosyal Bilimler Enstitüsü, Ankara.

Warnich, P. ve Gordon, C. (2015). The integration of cell phone technology and poll everywhere as teaching and learning tools into the school History classroom. Yesterday and Today, (13), 40-66.

Wong, A. (2016). Experience and techniques of using mobile phones and a polling web site as a student response system. International Journal of Management and Applied Science, 2(5), 45-49.

Yıldırım, A. ve Şimşek, H. (2013). Sosyal bilimlerde nitel araştırma yöntemleri. Ankara: Seçkin Yayınc1lik.

Yılmaz, F. (2014). Yeni Hitit Yabancılar İçin Türkçe 2 ders kitabı yazma etkinlikleri üzerine bir inceleme. Uluslararası Türk Eğitim Bilimleri Dergisi, 2(2), 37-48.

\section{Extended Abstract}

\section{Introduction}

Writing skill is developed on the basis of criteria such as "the use of language rules, awareness of form and sentence, vocabulary level" in teaching Turkish as a foreign language process. Educational situations designed for writing inside and outside the classroom must comply with the criteria listed above. Accordingly, besides the traditional writing activities, the use of the Web 2.0 tools developed within the frame of current technology level becomes crucial. Writing activities designed with Web 2.0 tools which allow alternative writing processes with their communication dimension can add new dimensions to the basis of the writing process.

The communicative dimension which forms an important dimension of educational environments designed with Web 2.0 tools is closely related to the writing skills. In this regard, in order for communication to take place, the text must be read by the audience. However, communicative writing can take place only when the author's text influences the audience, and the audience establishes a mutual relation between the text and themselves (Ülper, 2008). Additionally, writing activities designed in the communicative approach must be studentcentered and must enhance motivation, writing materials must be authentic, content and level must be appropriate for students, and materials must be linked to fun and daily life (Adiyaman, 2011, p. 17-18).

Web 2.0 tools such as Google Drive, Google Docs, E-mail, Facebook, Whatsapp, Twitter, Wiki, Blog can be used for writing skills. These Web 2.0 tools improve writing skills, expand the community that writing works aim at, increase motivation for writing, develop and liberate ideas, help with word choice, enable textual structures such as paragraphs to be recognized, change the negative view toward the publication of written products, allow collaborative writing and distant group work, promote peer support, inspire writing and creativity, convey personal thoughts and emotions, represent hobbies and experiences, offer debates (Ajjan \& Hartshorne, 2008; Alexander, 2006; Alsaleem, 2013; Bennett, Bishop, Dalgarno, Waycott \& Kennedy 2012; Brodahl, Hadjerrouit \& Hansen, 2011; Duffy, 2008; Fattah, 2015; Grosseck \& Holotescu, 2008; Grosseck, 2009; Ince \& Akdemir, 2013; Kalelioğlu \& Gülbahar, 2010; Özmen, Aküzüm, Sünkür \& Baysal, 2011; Shih, 2011; Sofia, 2015; Thompson, 2007).

This study aims to obtain student opinions about Poll Everywhere which is a Web2.0 tool and writing activities designed with it. Answers to the the questions mentioned below are are sought: 
1. What are the students' thoughts on Poll Everywhere Web 2.0 tool?

2. What are the students' thoughts on designed activities?

\section{Method}

In this study, embedded single case study is used. The research group of the study is composed of 5 female and 5 male students studying at B1 level at Y1ldı Technical University TÖMER. The activities designed within the scope of the research are prepared in accordance with communicative approach in three parts of the Poll Everywhere Web 2.0 tool. (Social Media, Book Worm, Which Movie?) (Appendix 1-3). The Word Cloud section was chosen to identify students' concepts or associations in order to develop ideas in the writing preparation process. Question-answer and open-ended question parts are used in sentence and paragraph-level exercises. The question-answer section is considered to be appropriate for peer evaluation because of the scoring system (scoring-ranking) it contains. The three activities are executed in two days, six hours at total. At the end of this process, students were given "Semi-structured Interview Form" prepared in accordance with the aim of the study by the researchers in order to determine students' thoughts about the prepared activities and poll Everywhere Web 2.0 tool. This interview form was prepared in the "Poll" section of Poll Everywhere and consists of ten open-ended questions, five of which are for the Poll Everywhere application and five for the prepared events. Content analysis was applied to the analysis of the data received from interview questions. As a result of the content analysis of the received data, the data were evaluated under the two categories of findings of Poll Everywhere Web 2.0 tool and designed activities.

\section{Result and Discussion}

Findings of the study regarding Poll Everywhere show that vast majority of the students enjoyed Poll Everywhere and reported positive feedback on its features.

According to the students participated in the study, Poll Everywhere is defined as fun, easy, beneficial, good, interesting, impressive, exciting, original, fast, different and as repeatedly positive adjectives. When student answers are examined, it can be said that prominent features of Poll Everywhere are being fun, fast and easy. This is due to the fact that Poll Everywhere is technology and internet based, which is similar to virtual messaging systems that students use in their daily lives. Since Poll Everywhere is original, different and interesting, it is seen as an alternative to traditional writing materials; it is seen as an educational environment that is yielded since it is beneficial and effective meaning that prominent purpose of this Web 2.0 tool is also educational. According to student views, Poll Everywhere Web 2.0 tool creates an interactive classroom environment. The fact that the written works of the students are clearly displayed and students benefit from each other's ideas and written works are two important indicators that Poll Everywhere has created an interactive classroom environment. Students also pointed out that they can make group evaluations with this Web 2.0 tool. Students take group evaluation in two ways: to recognize errors in written works and to grade written works. At this point, it is possible to say that students are making a qualified evaluation by recognizing others' errors, by taking feedback on their own mistakes, and by scoring to select the best written work. Many features which Poll Everywhere Web2.0 tool has increase the desire to write. At this point, the classified author identity feature which does not show the name of the author is the prominent element that increases the desire to write. Finally, it is possible to say that the use of the Poll Everywhere Web 2.0 tool is appropriate for each course of writing.

Findings of the study regarding the activities designed with Poll Everywhere Web 2.0 tool show nearly all students have positive perceptions about the activities. Additionally, activities show competences in terms of communicative approach such as interpersonal communication, author audience relationship, student interest-desire and needs, student motivation; in terms of content such as relevance to levels, up-to-dateness, group work, and having fun. It can be said that the designed activities allow students to express personal thoughts 
freely, that they are appropriate to the language level, that they are interested, that they increase the level of knowledge, that they are related to their daily life and their taste, that they are different from each other in terms of content and technique. Additionally, students enjoy activities which provide many different ideas and opportunities, which offer interpersonal interactions, and which are related to daily life. Activities designed by using Poll Everywhere Web 2.0 tool are generally more advantageous than traditional writing activities in the textbook. Some of the differences in favor of the designed activities are that the activities are interesting, diverse, different and up-to-date, simple and easy to make, and the scope is wide. According to student opinions, the activities are beneficial in terms of creative and critical writing skills. The development of critical writing skills by activities can be explained both by producing arguments for or against an idea, and by evaluating others' arguments. The development of creative writing skills stems from the fact that the subjects of activities, their purposes and their scope are different and challenging. Finally, it can be said that the activities are compatible with the Poll Everywhere Web 2.0 tool.

EK 1

Poll Everywhere Web 2.0 Aracı İçin Hazırlanmış Etkinlikler

\begin{tabular}{|c|c|}
\hline Sosyal Medya & $\begin{array}{l}\text { Yazma } \\
\text { Bölümü }\end{array}$ \\
\hline İnternetsiz bir hayatı üç kelime ile tanımlayınız. & $\begin{array}{l}\text { Kelime } \\
\text { Bulutu }\end{array}$ \\
\hline $\begin{array}{l}\text { Aşağıdaki sorulardan birini cevaplayınız. } \\
\text { - İnternet üzerinden ilginç ve farklı birisiyle tanıştınız mı? Bu kişi hakkında } \\
\text { bilgi veriniz. } \\
\text { • İlginç ve farklı bir İnternet sitesi biliyor musunuz? Bu İnternet sitesini } \\
\text { kisaca anlatınız. }\end{array}$ & $\begin{array}{l}\text { Soru } \\
\text { Cevap }\end{array}$ \\
\hline $\begin{array}{l}\text { Facebook, Twitter, İnstagram, Snapchat vb. uygulamaları bir hayvana, bitkiye, } \\
\text { eşyaya benzetiniz. Sebebini yazını. } \\
\text { Örnek: Facebook bir kediye benziyor. Çünkü kediler insanın dikkatini dă̆ı̆tacak } \\
\text { şeyler yapabiliyor. Facebook'dan bildirim geldiğinde dikkatim bozuluyor. } \\
\text { İnstagram bir pencereye benziyor. Çünkü instagramın içinde harika doğa } \\
\text { fotoğrafları var. }\end{array}$ & $\begin{array}{l}\text { Soru- } \\
\text { cevap }\end{array}$ \\
\hline $\begin{array}{l}\text { Herhangi bir sosyal medya uygulamasında ünlü olduğunuzu ve iki milyon } \\
\text { takipçinizin olduğunu hayal ediniz. Sizi ünlü yapan sebebi bir paragrafta } \\
\text { açıklayınız. }\end{array}$ & $\begin{array}{l}\text { Açık } \\
\text { uçlu soru }\end{array}$ \\
\hline $\begin{array}{l}\text { "Ömer } 1930 \text { yılında yaşayan genç bir adamdır. Her gün merakla postaneye gidip } \\
\text { kendisine mektup gelip gelmediğini kontrol ediyor. Yaklaşı } 3 \text { ay önce gönderdiği } \\
\text { mektuba sabırsızlıkla cevap bekliyor. Ömer, bir gece kendisine mektup gelmediği } \\
\text { için üzülerek uykuya dalıyor. Sabah uyandığında tarih } 2017 \text { oluyor. Ömer } \\
\text { şaşkınlıkla elinde titreyen garip nesneye bakıyor...” } \\
\text { Hikâyenin devamını yazınız. }\end{array}$ & $\begin{array}{l}\text { Açık } \\
\text { uçlu soru }\end{array}$ \\
\hline $\begin{array}{l}\text { "Skype, Whatsapp, Facebook gibi uygulamalarla sevdiklerimizle görüntülü bir } \\
\text { şekilde kolayca konuşabiliyoruz. Gelecekte teknolojik aletler sayesinde uzaktaki } \\
\text { birisinin dokunuşunu da hissedeceğiz. Ayrı ca bu kişiyi üç boyutlu şekilde göreceğiz. } \\
\text { Bu yüzden insanları bir arada olmasına gerek kalmayacak.” Bu fikre katıliyor } \\
\text { musunuz? Neden? }\end{array}$ & $\begin{array}{l}\text { Açık } \\
\text { uçlu soru }\end{array}$ \\
\hline $\begin{array}{l}\text { Aşağıdaki sorulara göre bir sosyal medya uygulaması tasarlayınız. } \\
\text { - Uygulamanızın adı ne olacak? } \\
\text { - Bu uygulamayı hangi amaçla tasarlayacaksınız? } \\
\text { - Uygulamanın özellikleri ne olacak? }\end{array}$ & $\begin{array}{l}\text { Açık } \\
\text { uçlu soru }\end{array}$ \\
\hline
\end{tabular}




\begin{tabular}{|c|c|}
\hline Kitap Kurdu & $\begin{array}{l}\text { Yazma } \\
\text { Bölümü } \\
\end{array}$ \\
\hline $\begin{array}{l}\text { • Şiir ... gibidir. } \\
\text { • Roman... gibidir. } \\
\text { Yukarıdaki boşlukları, önce şiir sonra roman için tek kelime ile doldurdunuz. }\end{array}$ & $\begin{array}{l}\text { Kelime } \\
\text { Bulutu }\end{array}$ \\
\hline $\begin{array}{l}\text { Aklınıza gelen ilk kelimeyi aşağıya yazınız. Arkadaşlarınızın da kelime yazmasını } \\
\text { bekleyiniz. Daha sonra bu kelimelerden ilginç ve farklı bir kitap adı oluşturunuz. }\end{array}$ & $\begin{array}{l}\text { Kelime } \\
\text { Bulutu }\end{array}$ \\
\hline $\begin{array}{l}\text { Sevdiğiniz bir roman kahramanın canlı olduğunu ve onunla sohbet ettiğinizi } \\
\text { düşünün. Bu roman kahramanının kim olmasını istersiniz? Ona hangi soruları } \\
\text { sorarsınız? }\end{array}$ & $\begin{array}{l}\text { Soru- } \\
\text { Cevap }\end{array}$ \\
\hline $\begin{array}{l}\text { “Ahmet kitabın son sayfasını okuyup yavaşça uykuya daldı. Uyandığında gözlerine } \\
\text { inanamadı. Çünkü okuduğu hikâyenin içindeydi ve hikâyenin ana karakteriydi. } \\
\text { Üstelik kitabın başlangıç noktasındaydı. Şimdi ne yapacağım, diye düşündü. Bu } \\
\text { karakterin hayatını zaten biliyordu. Beş gün sonra ölecekti...” } \\
\text { Hikâyenin devamını yazını. }\end{array}$ & $\begin{array}{l}\text { Açık } \\
\text { uçlu soru }\end{array}$ \\
\hline $\begin{array}{l}\text { "Bir kitabın filmi çekilmişse o kitabı okumam. Filmi izlemeyi tercih ederim. Çünkü } \\
\text { bu kitabı okumayı ancak } 10 \text { saatte bitirebilirim. Fakat film hâlini } 2 \text { saatte } \\
\text { izleyebilirim. Böylece hem zamandan tasarruf ederim hem de daha eğlenceli vakit } \\
\text { geçiririm. Sonuçta ikisi de aynı şeyi anlatıyor." diyen birisinin fikrine katıllyor } \\
\text { musunuz? Neden? }\end{array}$ & $\begin{array}{l}\text { Açık } \\
\text { uçlu soru }\end{array}$ \\
\hline $\begin{array}{l}\text { İnsanlar geçmiş zamanlarda taşa, ağaç kabuğuna, parşömene, deriye yazılar yazmış. } \\
\text { Sizce kitabın geleceği ne olacak? Kitaplar kâğıda basılmaya devam edecek mi? } \\
\text { Yoksa tamamen elektronik ortama mı geçecek? Fikrinizi açiklayınız. }\end{array}$ & $\begin{array}{l}\text { Açık } \\
\text { uçlu soru }\end{array}$ \\
\hline
\end{tabular}

\begin{tabular}{|l|l|}
\hline Hangi Film? & $\begin{array}{l}\text { Yazma } \\
\text { Bölümü }\end{array}$ \\
\hline $\begin{array}{l}\text { Sizce bir insan ne için film izler? ( “..... mak/mek için” şeklinde cevap veriniz. } \\
\text { Örnek: hayata farklı bir pencereden bakmak için. }\end{array}$ & $\begin{array}{l}\text { Kelime } \\
\text { Bulutu }\end{array}$ \\
\hline $\begin{array}{l}\text { Aklınıza gelen ilk kelimeyi aşağıya yazınız. Arkadaşlarınız da kelime yazmasını } \\
\text { bekleyiniz. Daha sonra bu kelimelerden ilginç ve farklı bir film adı oluşturunuz. }\end{array}$ & $\begin{array}{l}\text { Kelime } \\
\text { Bulutu }\end{array}$ \\
\hline $\begin{array}{l}\text { Bir süper kahraman filmi çekeceğinizi düşünün. Sınıf arkadaşlarınızdan biri bu } \\
\text { filmde oynayacak. Arkadaşlarınızdan birini seçiniz. Bu arkadaşınızın süper } \\
\text { gücünün ne olacağını yazınız ve sebebini açıklayınız. }\end{array}$ & $\begin{array}{l}\text { Soru- } \\
\text { Cevap }\end{array}$ \\
\hline $\begin{array}{l}\text { Fatma, başını televizyonun ekranına yaklaştırıor. Bir gerilim filmi izlediği için çok } \\
\text { heyecanlı. Yaşlı adamın başına ne geleceğini merak ediyor. }\end{array}$ & \\
$\begin{array}{l}\text { "Yaşlı adam, ağır ağır merdivenleri çıkyyor. Sonunda evinin önüne geliyor. Fakat } \\
\text { kapının aralık olduğunu fark ediyor. İçeriden sarı bir ışık geliyor. Acaba evine } \\
\text { birisi mi girdi? Belki ışı̆̆ı ve kapıyı kendisi açık bıraktı. Yaşlı olduğu için hafizası } \\
\text { kuvvetli değil. Her şeyi çabuk unutuyor...” } \\
\text { Filmin devamını yazını. }\end{array}$ & $\begin{array}{l}\text { Açık } \\
\text { Uçlu } \\
\text { Soru }\end{array}$ \\
\hline $\begin{array}{l}\text { Sizin için bir filmde aşağıdaki seçeneklerden hangisi daha önemlidir? Neden? } \\
\text { a. Oyunculuk b. Senaryo c. Görsel Efektler }\end{array}$ & $\begin{array}{l}\text { Açık uçlu } \\
\text { soru }\end{array}$ \\
\hline $\begin{array}{l}\text { Birçok bilim kurgu filminde ileri teknoloji ile ilgili şeyler vardır. Örneğin } \\
\text { 1şıllanma, zamanda yolculuk, kanser ilacı, ölümsüzlük, bilinçli robotlar, başka bir } \\
\text { gezegende yaşamak. Sizce insanlar ileri teknolojiye ulaşabilecek mi? Yoksa bu } \\
\text { filmlerdeki teknolojik gelişimler sadece hayal mi? }\end{array}$ & $\begin{array}{l}\text { Açık uçlu } \\
\text { soru }\end{array}$ \\
\hline
\end{tabular}

